\title{
Hydrolytic activity in a full-scale aerobic granular sludge reactor
}

\author{
Sara Toja Ortega ${ }^{1}$, Mario Pronk ${ }^{1}$, and Merle de Kreuk ${ }^{1}$ \\ ${ }^{1} \mathrm{TU}$ Delft
}

November 10, 2020

\begin{abstract}
Aerobic granular sludge (AGS) is applied worldwide to treat domestic and industrial wastewater. Complex substrates, like proteins, carbohydrates and lipids, are major components of domestic wastewater, but their utilization by AGS is not well understood. Since hydrolysis is considered the rate limiting step in the bioconversion of complex substrates, the activity of major hydrolytic enzymes was investigated in the different sludge fractions of a full-scale AGS reactor. Lipase, protease, $\alpha-$ glucosidase and $\beta$-glucosidase activities were assessed in large granules ( $>1 \mathrm{~mm}$ diameter), small granules $(0.2-1 \mathrm{~mm})$, flocculent sludge $(0.045-0.2 \mathrm{~mm})$ and bulk liquid. Besides, composition and hydrolytic activity of influent wastewater samples were determined. The highest specific hydrolytic activity was associated with the flocculent sludge fraction (1.5 - 7.5 times that of large and smaller granules). However, the biomass in the full scale reactor consisted of $84 \%$ large granules, making the large granules account for $55-68 \%$ of the total hydrolytic activity potential in the reactor. These results suggest that large granules can hydrolyse a significant fraction of the polymeric COD under anaerobic feeding conditions, and support the stable granule formation and the biological phosphate removal process observed in full scale installations.
\end{abstract}

\section{Hosted file}

Main text.pdf available at https://authorea.com/users/374500/articles/492053-hydrolyticactivity-in-a-full-scale-aerobic-granular-sludge-reactor

\section{Hosted file}

Table 1.pdf available at https://authorea.com/users/374500/articles/492053-hydrolyticactivity-in-a-full-scale-aerobic-granular-sludge-reactor

\section{Hosted file}

Table 2.pdf available at https://authorea.com/users/374500/articles/492053-hydrolyticactivity-in-a-full-scale-aerobic-granular-sludge-reactor

\section{Hosted file}

Table 3.pdf available at https://authorea.com/users/374500/articles/492053-hydrolyticactivity-in-a-full-scale-aerobic-granular-sludge-reactor 

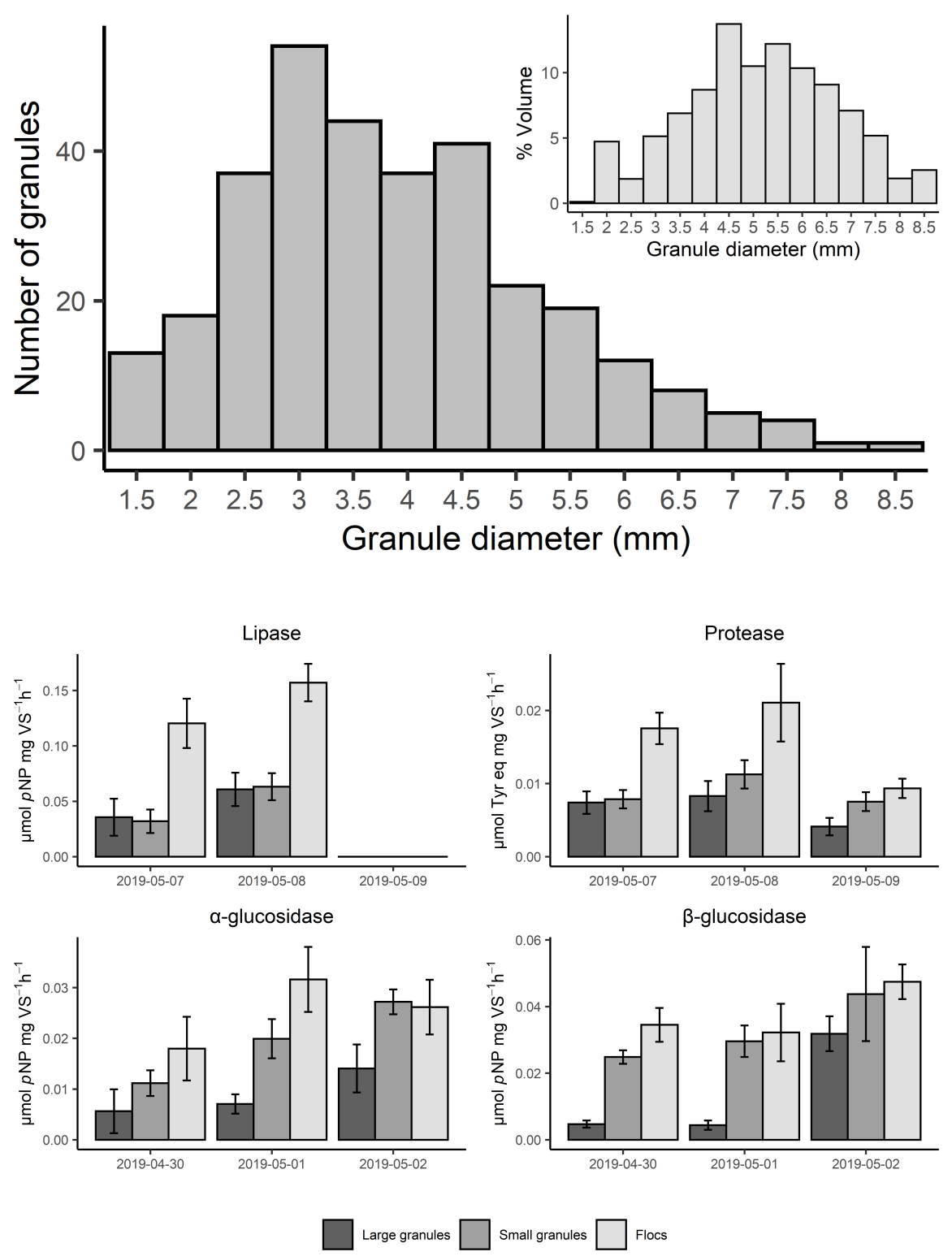


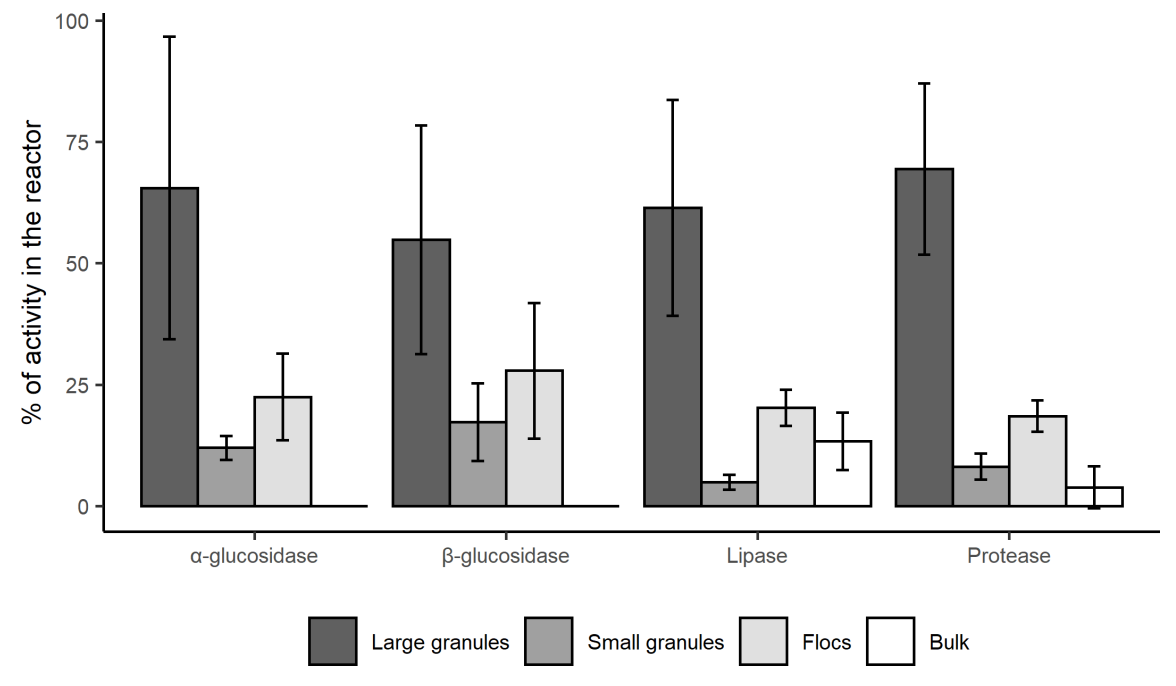


A

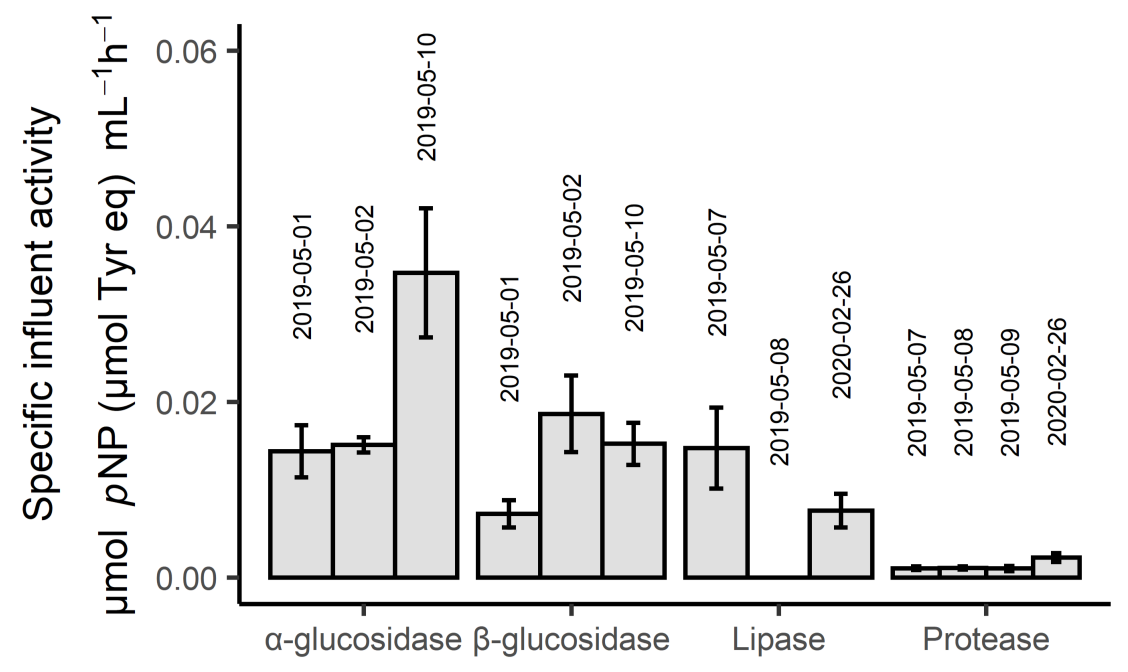

B

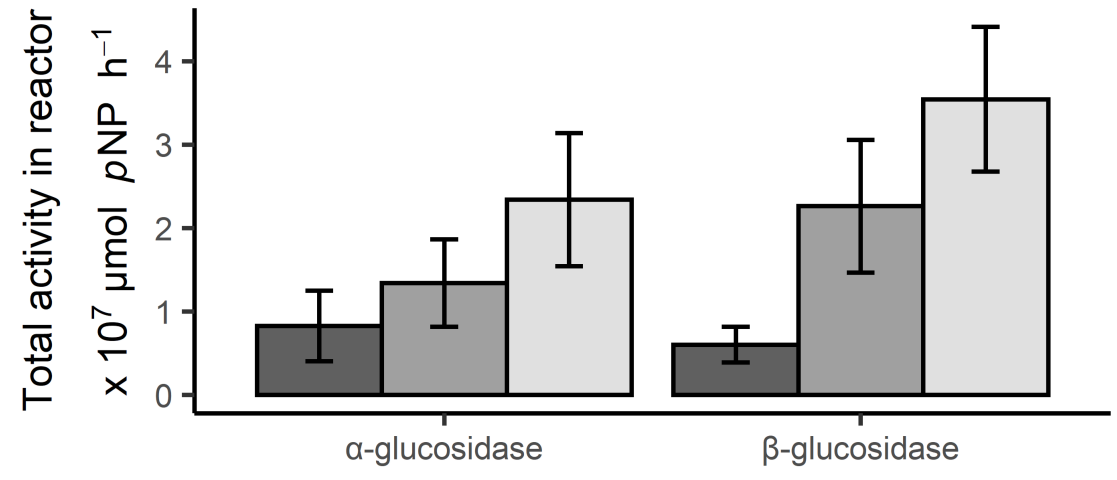

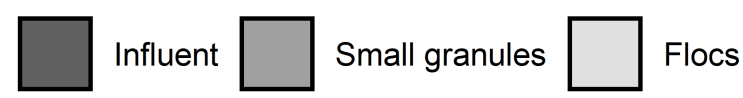




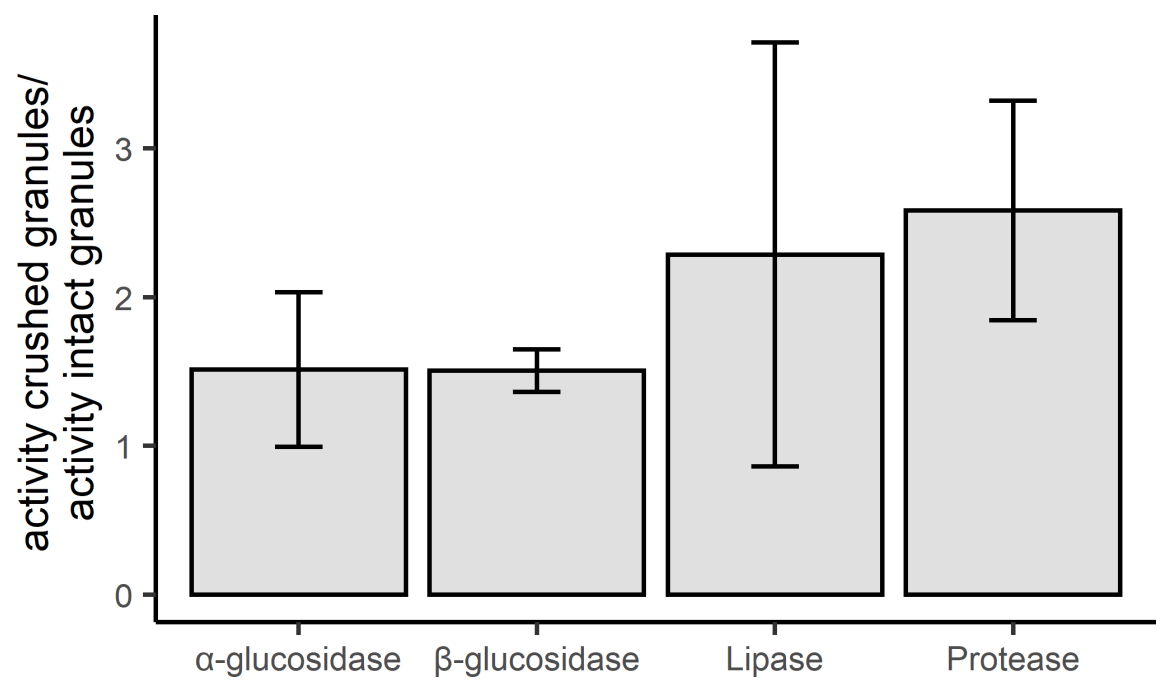

